$16 \mid 2020$

Les marges créatrices : intellectuel.le.s afrodescendant.e.s et indigènes auX Amériques, XIX-XXe siècle

\title{
Les Amérindiens de l'ère progressiste à la reconquête de leur souveraineté intellectuelle
}

Progressive Era Native Americans and intellectual sovereignty

Los indígenas estadounidenses en la lucha por la soberanía intelectual durante la era progresista

\section{Lionel Larré}

\section{OpenEdition}

\section{Journals}

Édition électronique

URL : http://journals.openedition.org/ideas/9026

DOI : 10.4000/ideas.9026

ISSN : $1950-570$

Éditeur

Institut des Amériques

Référence électronique

Lionel Larré, «Les Amérindiens de l'ère progressiste à la reconquête de leur souveraineté

intellectuelle », IdeAs [En ligne], 16 | 2020, mis en ligne le 01 octobre 2020, consulté le 19 octobre 2020. URL : http://journals.openedition.org/ideas/9026 ; DOI : https://doi.org/10.4000/ideas.9026

Ce document a été généré automatiquement le 19 octobre 2020.

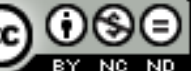

IdeAs - Idées d'Amériques est mis à disposition selon les termes de la licence Creative Commons Attribution - Pas d'Utilisation Commerciale - Pas de Modification 4.0 International. 


\title{
Les Amérindiens de l'ère progressiste à la reconquête de leur souveraineté intellectuelle
}

\author{
Progressive Era Native Americans and intellectual sovereignty \\ Los indígenas estadounidenses en la lucha por la soberanía intelectual durante \\ la era progresista
}

Lionel Larré

\section{Introduction}

1 Les études amérindiennes sont nées dans les universités nord-américaines dans les années 1970, dans le sillage des mouvements militants pour les droits civiques et de ce que l'on a appelé la Renaissance amérindienne, marquée par l'obtention du prix Pulitzer par l'auteur kiowa N. Scott Momaday pour son roman House Made of Dawn, en 1969, et la publication la même année du manifeste de Vine Deloria Jr., Custer Died for Your Sins.

Dans ces circonstances d'émergence, les études amérindiennes ont longtemps ignoré l'ère progressiste $d u$ tournant $d u x^{e}$ siècle, pendant laquelle la production intellectuelle amérindienne fut pourtant d'une très grande richesse. Parce qu'ils n'y ont pas regardé de près, les chercheurs des années 1970 aux années 1990 ont longtemps perçu les intellectuels amérindiens du début $d u x^{e}$ siècle comme essentiellement assimilationnistes et ont préféré s'intéresser aux écritures de revitalisation identitaire de la seconde moitié du siècle, plus aisément perçues comme des écritures de résistance. Une notable exception fut l'ouvrage de Hazel W. Hertzberg, The Search for an American Indian Identity: Modern Pan-Indian Movements, qui propose dès 1971 une étude de la Society of American Indians (SAI), une organisation d'intellectuels et militants amérindiens entre 1911 et 1923. Sur la base du travail de Hertzberg, ce n'est que plus récemment qu'un travail d'exhumation des archives et de réhabilitation des 
intellectuels amérindiens de l'époque a été entrepris, notamment par Frederick Hoxie avec une anthologie de textes de la période, Talking Back to Civilization, Indian Voices from the Progressive Era (2001), Lucy Maddox avec Citizen Indians: Native American Intellectuals, Race, and Reform (2005), Chadwick Allen et ses co-auteurs d'un numéro conjoint de SAIL (Studies in American Indian Literature) et AIQ (American Indian Quarterly) consacré en 2013 à la SAI, et l'auteur du présent article avec l'édition en 2012 d'un volume des écrits de John Milton Oskison, intellectuel cherokee prolifique du début du siècle. Aujourd'hui, de plus en plus de chercheurs s'intéressent aux militants amérindiens de cette période et s'attachent à corriger l'attitude qu'ont eue à leur égard les chercheurs, intellectuels et militants amérindiens de la deuxième moitié $d u x^{e}$ siècle - « so many of the Native leaders, activists, and scholars who have come after the SAI, especially since the 1960s, have found its members and their ideas problematic or, worse, irrelevant " (Allen C., 2013 : 5) - même si certains sont encore mal à l'aise vis-à-vis des positions prises par ces militants de l'ère progressiste :

The anxiety these figures generate, though, is not simply a matter of their being misguided or disconnected. They regularly and easily outshine subsequent generations in their careful deliberations and presence in the Native world in the work they did. But all the talk of patriotism and acceptance of US exceptionalism is tough to ignore, and even tougher to read through the lenses of subversion of resistance.

(Warrior R., 2013 : 226)

3 Ce que les historiens appellent l'ère progressiste, aux États-Unis, est une période fondamentale, notamment dans l'histoire intellectuelle nord-amérindienne, une histoire qu'il est nécessaire de mieux comprendre si l'on souhaite déconstruire la vision d'une passivité victimaire trop souvent attribuée aux Amérindiens. Ces derniers, au contraire, ont été les agents actifs de leur histoire, y compris sur le plan intellectuel et discursif, et de façon très prolifique tout spécialement à la fin du xix ${ }^{e}$ siècle et pendant les trois premières décennies $\mathrm{du} \mathrm{xx}^{\mathrm{e}}$ siècle. Les bornes amérindiennes de cette période coïncident avec la fin de ce que l'historiographie appelle les " guerres indiennes », plus précisément le massacre de Wounded Knee en 1890, et le New Deal Indien (Indian Reorganization Act) de 1934. Durant cette période, toutes celles et tous ceux qui avaient à cœur de résoudre «le problème indien » semblent s'être concertés pour produire une pensée riche et complexe. De nombreux philanthropes euro-américains «amis des Indiens " avaient une influence considérable sur les politiques indiennes fédérales. Mais de très nombreux auteurs de cette production intellectuelle étaient eux-mêmes amérindiens. Dans un travail en cours de recensement systématique des données de la recherche sur le sujet, je compte pour l'heure plus de trois cents textes produits par quelque cent trente auteurs différents dans diverses publications périodiques et actes de conférences. Certains sont des figures bien connues dans les études amérindiennes : Arthur Parker, Carlos Montezuma, Charles Alexander Eastman, Gertrude Bonnin (Zitkala-Sa), John Milton Oskison. Parmi les autres, beaucoup méritent d'être redécouverts. Ils ont abordé tous les sujets brûlants de l'époque: la vie dans les réserves, l'individualisation de la propriété, l'éducation, les politiques d'assimilation, la citoyenneté états-unienne, la préservation culturelle, etc. Ils étaient journalistes, avocats, enseignants, membres du clergé, médecins, infirmières, ethnologues, écrivains, membres du Congrès, fonctionnaires du Bureau des Affaires indiennes.

4 Ces professions pourraient a priori remettre en question le statut marginal de ces intellectuels. Après tout, peut-on réellement prétendre que John Milton Oskison, 
journaliste au Collier's Weekly et au New York Evening Post, Robert L. Owen (cherokee), sénateur de l'État d'Oklahoma, le médecin Charles Alexander Eastman (sioux) étaient en marge de la société états-unienne? Pourtant, la position centrale de quelques individus ne saurait guère remettre en cause la position marginale dans laquelle se trouvaient l'ensemble des Amérindiens en tant que tels. La plupart étaient dans une marge physique et géographique d'abord, puisqu'ils étaient confinés dans des réserves. De nombreuses voix amérindiennes relevaient d'ailleurs à quel point ces réserves allaient à l'encontre des objectifs assimilationnistes fixés par les politiques fédérales. C'est dans une marge discursive, ensuite, qu'ils se trouvaient, mais de façon cette fois volontaire, pour mieux l'investir de toute leur puissance créatrice, avant de tenter de la recentrer. C'est ainsi que quelques intellectuels, qui se trouvaient parfois invités à exprimer leur point de vue auprès des philanthropes réformateurs euro-américains constituant l'organisation connue sous le nom de Lake Mohonk Conference of Friends of the Indian, ont décidé en 1911 qu'ils seraient plus libres, et peut-être plus efficaces, au sein de leur propre organisation, la Society of American Indians, « the first American Indian rights organization conceived, developed, and run by Native people themselves, rather than by sympathetic non-Native reformers or other so-called Friends of the Indians " (Allen C., $2013: 3-4$ ).

5 Loin de l'exhortation à l'assimilation qu'y ont vue la plupart des chercheurs en études amérindiennes pendant longtemps, on peut déceler dans la production discursive des militants amérindiens de cette époque une reconquête de souveraineté intellectuelle, dont l'enjeu était une nouvelle forme de résistance, non contre la modernité et le progrès, mais contre le mythe du Vanishing American et les autres représentations dégradantes. On y trouve des stratégies de préservation identitaire en même temps que de négociation d'intégration dans la société états-unienne. Cette résistance et ces stratégies passaient non seulement par la production de représentations des Amérindiens qui remettaient en question les représentations imposées par le discours dominant, mais également par la valorisation de toute la potentialité créatrice que les Amérindiens pouvaient mettre au bénéfice de la société états-unienne.

\section{Reconquête de souveraineté intellectuelle}

6 Les « amis des Indiens » étaient nombreux à la fin du XIX ${ }^{e}$ siècle à se sentir investis de la mission paternaliste de mener enfin à son terme le processus de "civilisation » des Amérindiens que George Washington et son Secrétaire à la Guerre Henry Knox avait entrepris dès la fin du XvIII ${ }^{e}$ siècle, et qui, selon eux, n'avait toujours pas abouti. Selon Washington et Knox, le projet civilisateur passait par la transformation des Amérindiens chasseurs en fermiers et éleveurs, comme l'explicite par exemple l'article 14 du Traité de Holston signé en 1791 avec les Cherokees : "That the Cherokee nation may be led to a greater degree of civilization, and to become herdsmen and cultivators, instead of remaining in a state of hunters, the United States will from time to time furnish gratuitously the said nation with useful implements of husbandry. »

7 À la fin du XIX $x^{e}$ siècle, le projet civilisateur, s'il n'est pas strictement identique à l'idéal agraire jeffersonien que l'on décèle dans l'extrait précédent, ne s'en éloigne guère puisqu'il s'agit notamment d'abolir la propriété collective des terres pour en allouer des parcelles aux individus amérindiens, en vertu de la loi Dawes de 1887 (Allotment of Lands in Severalty Act) fortement promue par « les amis des Indiens ». 
Depuis 1883, la Lake Mohonk Conference of Friends of the Indian, réunissait chaque année sur les bords du lac Mohonk, dans l'Etat de New York, tout ce que l'élite états-unienne comptait de philanthropes et réformateurs intéressés par la résolution du "problème indien ». C'est son fondateur, Albert K. Smiley, qui est le plus à même d'expliquer l'origine de l'organisation et de la conférence annuelle :

For many years, ever since the organization of our Board of Indian Commissioners, it has been their practice to have a Convention in connection with the annual meeting, in Washington, to discuss Indian affairs generally. To that Convention the secretaries and well-known members of religious denominations have been invited, and they have generally been present, as well as members of Congress and others. In these discussions, usually occupying one day, we have always found that the time was short. The pressure of business in Washington was so great that we could not hold people together more than one day, and we have had to adjourn before we were through. So the thought struck me a few years ago that we could give more time to the subject by inviting friends of the cause to this house and having a threedays' Conference. I suggested the idea to some of my friends and they approved of it, and that is the way this Conference originated.

My aim has been to unite the best minds interested in Indian affairs, so that all should act together and be in harmony, and so that the prominent persons connected with Indian affairs should act as one body and create a public sentiment in favor of the Indians.

(Lake Mohonk Conference, $1886: 3$ )

9 Ainsi, membres du Congrès, missionnaires religieux, et autres "amis des Indiens" étudiaient ensemble les moyens à employer pour parachever le processus de civilisation des Amérindiens, et exerçaient une influence considérable sur les politiques fédérales. Dans les actes de la conférence annuelle, on trouve quelques rares interventions de participants amérindiens: Francis La Flesche (omaha) intervient en 1900 ; Charles Doxon (onondaga) y promeut l'éducation professionnelle des Indiens en 1906; la même année, Oskison y explique qu'il faut propager dans la presse et la littérature des histoires positives au sujet des Amérindiens; Henry Roe Cloud (winnebago) intervient en 1910 sur «quelques aspects socio-économiques de la réserve ». Pendant une trentaine d'années, les voix amérindiennes ont du mal à se faire entendre parmi le discours paternaliste et assimilationniste des « amis des Indiens » du lac Mohonk.

C'est ainsi qu'en 1911, un groupe comprenant certains de ceux qui étaient occasionnellement invités à s'exprimer à la conférence du lac Mohonk fondent la Society of American Indians, déplorant dans la préface de son texte fondateur que l'Indien « n'ait pas son mot à dire sur sa destinée » (Society of American Indians, 1912:4). Au contraire, la nouvelle organisation revendique le droit des Amérindiens à peser sur leur destinée et s'engage à défendre les droits de tous les Amérindiens : "The Association asserts the right of the Indian to an active voice in the rights and destin of his race and will ever seek to defend all rights and just claims of the race » (SAI, 1912:14).

11 Dans une lettre adressée aux Amérindiens, et littéralement envoyée en 4000 exemplaires à autant d'adresses d'Amérindiens à travers le pays, l'association pose la question rhétorique : "Is he to continue to be the creature of outside forces? » Elle répond fermement : « Every Indian says, No!» (SAI, 1912: 15). Le positionnement de la SAI par rapport à la Conférence du Lac Mohonk des Amis des Indiens est clair :

We earnestly believe the time has come when the American Indian should take the initiative in the struggle for his race betterment, and to answer in his own way some of the vital questions that confront him. [...] Mistaken work will continue 
unless the Indian expresses himself, for no one knows the heart of the Indian as the Indian himself.

An organization that shall voice the best judgment of the Indian people, and that shall command the attention of the United States has become a vital necessity.

(SAI, $1912: 15-16)$

Ainsi, l'intérêt fondamental que les très nombreux textes écrits par les Amérindiens de l'époque présentent est autant dans leur nature que dans leur contenu. Outre les idées qu'ils véhiculent et les positions qu'ils expriment, ces textes doivent être analysés en tant qu'actes, puisqu'ils sont tous des manifestations de la prise d'une parole jusque-là confisquée, ou tout du moins ignorée, des manifestations discursives de l'agentivité des Amérindiens. Il est impossible, dans le cadre de cette contribution, de rentrer dans l'analyse détaillée de ce qu'apporte cette riche production discursive sur le plan des idées relatives aux thèmes qu'ils abordent et cités dans l'introduction. Il suffira peutêtre pour l'heure de comprendre les enjeux de la prise de parole que cette production discursive constitue.

La volonté des fondateurs de la SAI est également de former un mouvement panindien : "The first step in this direction is, we believe, the revival of the old face-to-face discussion around the "Old Council Fire" composed of men and women not of one tribe only but of all the tribes in the United States » (SAI, 1912:16).

Ils s'inscrivent explicitement dans les pas de Tecumseh, un leader shawnee qui, à l'aube de la guerre de 1812, c'est-à-dire un siècle avant la création de la SAI, avait tenté une alliance panindienne aux côtés des Anglais contre les États-Unis :

For a century at least the thinking American Indian has dreamed of [an] organization for the purpose of the protection and the advancement of his race. There have been many successful attempts in the annals of the aboriginal American race to confederate certain tribes and nations, and even parts of different linguistic stocks have united for mutual purposes, but the idea of uniting the entire race or a considerable portion of it within a large geographical area heretofore does not seem to have impressed any Indian as strongly as Tecumseh, the famous Shawnee.

(SAI, 1912:3)

15 A la différence de Tecumseh, cependant, la SAI n'aspire en aucun cas à une indépendance séparatiste, mais bien à une souveraineté démocratique au sein des États-Unis : «This is a representative government and it is time we were heard » (SAI, $1912: 16)$.

16 Cette prise de parole et ce travail d'autodéfinition passent nécessairement par une remise en cause profonde de la relation paternaliste que le gouvernement fédéral a nourrie avec les Amérindiens, et que les «amis des Indiens » ont épousée. Dans la préface des actes de la première conférence de la SAI, les fondateurs écrivent :

A reservation does not afford a normal condition of human environment, the condition of wardship is not conducive of independence or of development. The paternal system of the Federal Government which now exercises control over about 300,000 native Americans has bred many gross evils, and the Indian of today as a result of that system finds himself unable to assert himself in a natural way. He is allowed no voice in his destiny, for it is the paternal hand of "the Great White Father" that assumes the right to guide him.

(SAI, $1912: 4$ )

17 Par cette reconquête de leur voix, une reconquête de leur souveraineté intellectuelle et discursive, les intellectuels de la SAI se distinguent de la conférence du lac Mohonk et 
se placent également dans une posture nuancée et constructive de résistance à l'assimilationnisme prôné par cette dernière.

\section{Une attitude constructive par rapport à l'assimilation}

18 L'inscription explicite des intellectuels de la SAI dans l'héritage de la résistance armée de Tecumseh peut étonner. Pourtant, l'objectif ultime des uns comme de l'autre était bien le même : mettre un terme à "l'oppression » des peuples amérindiens par les peuples européens qui ont « envahi l'Amérique ». Même si elle doit se mener avec des armes différentes, les fondateurs de la SAI soulignent dans la préface des actes de leur première conférence que cette lutte est toujours d'actualité :

The common ground which every tribe had in Tecumseh's time was the oppression of the red race by the various divisions of the white race that had invaded America. Much of this oppression [...] was due to the natural misunderstanding that exists between races of radically different environments and different stages of ethnic culture. It was also due largely to the conception on the part of the white race that it had inherently superior rights and was morally justified in oppressing and exterminating the original occupant of America. Some of these ideas unfortunately exist today.

(SAI, $1912: 3$; je souligne)

Il s'agit pour les membres de la SAI de mener une résistance constructive pour enfin mettre un terme à ces préjugés, toujours présents, qui se traduisent par la mise à l'écart des Amérindiens. Une mise à l'écart physique dans les réserves, que certains considèrent comme un moyen d'oppression : Carlos Montezuma (apache yavapai), par exemple, parle des réserves comme des " prisons » dont il faut aider les Amérindiens à "s'échapper» (Montezuma C., 1914: 71). Dans un pamphlet intitulé « Let My People Go ", il écrit: "The reservation Indians are prisoners; they cannot do anything for themselves » (Montezuma C., 1916 : 33). Thomas L. Sloan, un avocat omaha, lors de la première conférence de la SAI, détaille par le menu les moyens mis en place par l'administration des réserves pour priver les Amérindiens de leurs droits les plus élémentaires, et dénonce clairement la complaisance des autorités politiques fédérales vis-à-vis des agents de l'administration indienne : «Public policy and political policy joined in the administration to deprive [the Indian] of his rights » (Sloan T. L., 1912: 113).

Il s'agissait aussi de résister contre une mise à l'écart sociale et culturelle, dans toutes ses dimensions, notamment éducative. De la même façon qu'il dénonce le système des réserves, Montezuma critique les écoles indiennes : «Purely Indian schools say to the Indian: "You are Indians, and must remain Indians; you are not of the nation, and cannot become of the nation. We do not want you to be of the nation" " (Montezuma C., $1914: 72)$.

21 L'ensemble du discours amérindien de l'époque peut se résumer en deux grands mouvements rhétoriques. Le premier est une analyse de l'inefficacité des politiques fédérales d'assimilation des Amérindiens dont la mise en œuvre est contre-productive :

The difficulties we find in our efforts to bring out the Indian as a man and a citizen among men are of our own creation. History, or even our own experience and common sense, ought to have shown us years ago that if we really wanted to civilize and assimilate the Indians, we were pursuing a course that must necessarily frustrate our designs.

(Montezuma C., $1914:$ 70) 
L'objectif affiché des politiques d'assimilation était d'intégrer les Amérindiens à la société états-unienne. Dans la très grande partie des écrits de l'époque, les Amérindiens appellent cette intégration de leurs vœux, même si elle ne prend pas nécessairement la forme d'une assimilation, comme nous le verrons dans un second mouvement. Montezuma, dans ses très nombreux écrits, ne rejette pas tant l'idée qu'il faille intégrer les Amérindiens, mais explique que la façon dont s'y prend le gouvernement porte en soi les raisons de son échec. Comment les Amérindiens peuvent-ils être intégrés si, confinés comme ils le sont dans les réserves, toute interaction avec la société étatsunienne leur est de fait interdite? Comment les enfants amérindiens et euroaméricains peuvent-ils mieux se connaître et se comprendre si on les place dans des écoles différentes?

Le second mouvement rhétorique du discours amérindien de l'ère progressiste est un appel aux États-Unis à laisser les Amérindiens contribuer, dans toute leur richesse créatrice et leur diversité, à la société, et même entrer en concurrence avec les autres membres de cette société pour ensemble la faire progresser. Montezuma déplore que le système éducatif tel qu'il est fait pour les Amérindiens étouffe leurs compétences et aptitudes naturelles qui devraient leur permettre de pleinement s'accomplir en tant que citoyens :

[O]ur Indian schools on the reservations are weak and inefficient because lacking in the essential elements of practical experience, association and competition, and not calculated to lift the Indian into the courage and ability to struggle and compete, but tend rather to create a fear of these conditions and make him shrink from the very competition necessary to enable him to reach his place as an independent man and citizen.

(Montezuma C., 1914 : 70)

Dans un texte prônant une éducation supérieure pour les Amérindiens, Bertram Bluesky (seneca) explique que les aptitudes naturelles des Amérindiens, dont l'histoire peut témoigner mais que la colonisation a étouffées, n'ont besoin que d'une éducation adéquate pour être ranimées, au bénéfice du pays :

Early history speaks of the Indian's powers of resistance and combination. When the Indian was overcome by a stronger race in the struggles for supremacy these powers were reduced to a latent state and overshadowed by the introduction of the forces of Eastern civilization. These latent powers are now being awakened to development, and are being fused with those forces which are contributing most to American progress today.

(Bluesky B., 1914 : 75)

La rhétorique de Bluesky, comme celle de Henry Knocksofttwo (sioux), qui écrit que " nous, les Indiens qui avons reçu une éducation du gouvernement, devons faire preuve de gratitude en mettant à profit ce que nous avons appris » (Knocksofttwo H., 1914 : 77 ; ma traduction), peut plus facilement que d'autres être interprétée comme une adhésion au projet assimilationniste et n'est pas exempte d'élans patriotiques: «The eyes of the whole nation of late have begun to be centered upon the college-bred Indian, and, to its wonderment, he seems to be weaving himself successfully and modestly into the fabric of the nation » (Bluesky B., 1914 : 75).

Il est cependant utile de contextualiser ce discours, qui s'oppose à celui de détracteurs euro-américains des dépenses publiques que le gouvernement engage en matière de politique indienne. Ainsi, Henry Knocksofttwo, dans un court texte intitulé « Educated Indians Are Successful » dans lequel il se montre très reconnaissant envers les États- 
Unis pour l'éducation qu'il reçut dans des pensionnats loin de la réserve, tente de contrer le préjugé relativement courant à l'époque que l'éducation des « sauvages » est une perte de temps et d'argent :

While many uninformed persons have been accustomed to point out the use[less]ness of educating the Indian by basing their contention on the more or less popular belief that no amount of education can prevent the Indian from reverting to the barbaric life of his nation, yet in my own district, among my fellow classmates, who have had this opportunity, all are at least self-respecting citizens, and enough members of the race have made good after having a chance to refute that belief to prove that it is an unfair position to take toward the Indian and his education.

(Bluesky B., 1914 : 77)

Ainsi, on le voit, même si le discours peut parfois sembler approuver l'assimilation en ne valorisant pas les particularismes culturels, il demeure un discours qui soit s'oppose aux représentations euro-américaines des Amérindiens, soit s'efforce de peser sur les modalités de mise en œuvre de la politique fédérale d'intégration. Quel que soit le degré d'acceptabilité du projet assimilationniste, l'idée de «contribution » des Amérindiens au développement de la société et de l'économie états-uniennes est récurrente. La préface des actes de la conférence de 1911 de la SAI fait état du rôle constructif que commencent à jouer les Amérindiens pour la nation: "Already the American Indian has proven his value as a constructive force in the State " (SAI, 1912 : 5). Dans ses objectifs, la SAI déclare :

The Association seeks to bring about a condition whereby the white race and all races may have a better and a broader knowledge of the red race, its claims, its needs and its ability to contribute materially and spiritually to modern civilization.

[...] One of its high aims is to see the development of conditions whereby the Indian as an individual and as a race may take his place as a man among men, as an active member of the great commonwealth, and independent of all support not accorded to any body of people who have achieved a position equal to the most enlightened. In stating this the Association emphatically asserts its belief that the Indian possesses natural ability and aptitude for every life mission and that under proper conditions these capacities will find a useful and successful development.

(SAI, $1912: 14-15$ )

Pour aller à l'encontre de ceux qui, à une époque où le darwinisme social et le racialisme scientifique sont monnaie courante dans le discours politique dominant, certains intervenants de la conférence insistent sur les qualités intrinsèques qui permettent aux Amérindiens de contribuer au progrès américain, quand on leur en donne les moyens. Oscar DeForest Davis (chippewa), dentiste, explique aux conférenciers que si les Amérindiens ne sont pas encore assez mis à contribution, ce n'est pas par manque de qualités et compétences, mais parce que le système actuel (les réserves, la ségrégation scolaire) ne le leur permet pas :

The Indian CAN do this and WILL as soon as the way has been indicated and he has been relieved of the retarding influences of the present system. [...] I believe he has natural qualities which especially fit him for professional work. His usually perfect physique and quiet, firm manner give him a personality which is invaluable to professional men. He is mechanical and has wonderful ability to work with his hands. This would add greatly to his success as a surgeon or dentist.

(DeForest Davis O., 1912 : 99) 
$\mathrm{Au}$ cours de la discussion qui suit cette intervention et celle de John Oskison sur le même sujet, Emma Goulette (pottawatomi), institutrice, enfonce le clou, et appelle à davantage de publicité de ces Amérindiens qui rencontrent le succès :

I regret very much that the majority of the people of the Caucasian race of the United States do not recognize the ability of the Indian to compete with the white race. So often we have found that the Indian who has received a training in the higher education, who has gone back and worked very energetically, has received very little recognition, and very little encouragement. I wish very much [...] that the members [...] of this Conference, would do their utmost in trying to acquaint the world - I don't mean the United States, I mean the world - with the abilities of the Indian.

(SAI, $1912:$ :101)

Emma Goulette lance ainsi un appel à la créativité des conférenciers pour propager des représentations du succès rencontré par les Amérindiens, une mission que se donne justement, entre autres, Oskison.

\section{Marge créatrice}

31 John Milton Oskison est l'un de ces auteurs que l'on a un peu trop rapidement qualifié d'assimilationniste alors qu'une analyse plus fine de ses écrits comme du contexte dans lequel ils s'inscrivent permet d'en faire un auteur nationaliste cherokee. Les premiers chercheurs à s'être un peu intéressés à Oskison lui ont reproché de ne pas avoir écrit au sujet des Indiens et de leurs préoccupations, alors que toute sa fiction se situe en territoire indien ${ }^{1}$. Selon Kirby Brown, Oskison écrit à une époque « considérée le plus souvent en termes résolument non nationalistes, soit trop accommodationnistes, voire carrément assimilationnistes » (Brown K., 2011, 79, ma traduction). Oskison est contemporain d'une période pendant laquelle les gouvernements tribaux en territoire indien sont abolis et le Chef principal cherokee nommé par le président des États-Unis seulement lorsque nécessaire ("les chefs d'un jour », Conley R. J., 2005 : 203). En cette période, le choix que fait Oskison d'écrire des romans et des nouvelles situés dans le territoire indien, et en particulier en terre cherokee, ou d'écrire les biographies de Tecumseh, grand résistant shawnee, et de John Ross, incarnation de la souveraineté et de la résistance cherokee, est un acte de résistance nationaliste et une manifestation de marge créatrice, dans la droite lignée du Cherokee Phoenix, le premier journal publié par des Amérindiens, dont le premier numéro date du 21 février 1828, et qui fut utilisé comme un instrument de propagande de la voix cherokee pendant leur confrontation à l'État de Géorgie, au président Andrew Jackson, et à sa loi de déportation (Removal Act, 1830).

Comme je l'ai écrit plus haut au sujet de la souveraineté intellectuelle reconquise par les militants amérindiens au début du $\mathrm{xx}^{\mathrm{e}}$ siècle, le nationalisme d'Oskison et d'autres n'est pas un nationalisme séparatiste. Il s'agit bien davantage d'une fierté culturelle et d'une volonté de la partager avec l'ensemble de la société.

Oskison se donne comme mission de propager des représentations des Amérindiens qui remettent en cause les idées préconçues dégradantes et mortifères. Il se sent investi de la responsabilité de projeter dans le monde des images d'Indiens progressistes: " My business, or profession, is writing and editing. In my small way, I've tried to make myself an interpreter to the world, of the modern, progressive Indian » (Oskison J. M., 
$1912 / 2012$ : 399). De la place marginale qui est celle des membres de la SAI, il appelle à la création de nouvelles représentations :

A new series of Indian portraits is needed. The "noble red man" of Fenimore Cooper and of Catlin, the fierce figure in war-paint and feathers, lost his romantic interest when he was confined to a reservation and fed on rations. He became of no more interest than any other stall-fed creature. Admiration of the untamed savage gave way to contempt for the dirty beggar in the streets and under the car windows [...] Now the stall-fed reservation dweller has been supplanted in turn by the new man, Indian only in blood and traditions, who is stepping up to take his place in the life of the West.

(Oskison J. M., 1907/2012:380)

L'écriture d'Oskison, comme l'ensemble du discours de ses confrères, est une manifestation de marges créatrices à plus d'un titre. D'une part, ces auteurs marginalisés sont créateurs de représentations et sont forces de propositions politiques, comme on l'a vu dans la partie précédente. D'autre part, ils représentent des Amérindiens qui ont en eux une force créatrice qu'ils mettent au service du pays et de la société, s'insinuant ainsi au centre de ce qui s'efforce de les repousser en marges. Sur le plan littéraire, Oskison est une bonne illustration de cette stratégie. Il situe ses nouvelles et ses romans en territoire indien, un territoire sur lequel le gouvernement fédéral avait marginalisé les Amérindiens, bien qu'il se situe paradoxalement en son centre géographique. Ce faisant, Oskison non seulement raconte des vies et un territoire qui se trouvent, à la fin du XIX ${ }^{e}$ siècle, au centre de toute l'attention de nombreux tenants économiques états-uniens (magnats des chemins de fers, spéculateurs fonciers, éleveurs de bétail, etc.), mais en plus, il produit une littérature qui s'inscrit pleinement dans la tradition littéraire régionaliste très en vogue aux ÉtatsUnis à la fin du XIX et au début du XX $x^{e}$ siècle :

There, ruled by tribal governments, was a region that was the meeting ground of Indians, blacks and northern and southern poor whites - a region that exhibited regional idiosyncrasies at least as unique as any that late nineteenth-century readers found appealing in fictional treatment of the South, the West, or New England.

(Littlefield, Jr D. F. \& J. W. Parins, 1982 : 23-24).

Angel de Cora, une artiste winnebago, enseignante à l'école indienne de Carlisle, et membre de la SAI, met en lumière pour le public de la conférence de 1911 la créativité artistique originale des Amérindiens et explique qu'il est nécessaire d'infuser cette puissance créatrice dans les arts décoratifs états-uniens, domaine dans lequel les compétences naturelles des Amérindiens en font, selon elle, des contributeurs uniques :

The Indians are gifted in original ideas of ornamentation as can be seen on their personal decorations. To train and develop this decorative instinct of the Indian to modern methods and apply it on up-to-date house furnishings is the nature and intent of the Native Indian Art Department as now carried on at the United States Indian School at Carlisle, Pennsylvania. The Indian's training for keen observation makes him an apt pupil in the pictorial art as those of you who have taught in Indian schools can readily verify.

(De Cora Dietz A., 1912 : 84)

36 A contre-pied de la mission assimilationniste et civilisatrice que les États-Unis se donnaient depuis plus d'un siècle vis-à-vis des Amérindiens, Angel de Cora explique que les motifs artistiques amérindiens peuvent permettre à l'Amérique du Nord de se défaire des traditions artistiques européennes et ainsi de pleinement se distinguer et développer une identité propre : 
Many of these designs have been thrown upon the market of the country and each one has brought its financial reward, but more than that, from these small and unassuming ventures, we have drawn the attention of artists and manufacturers to the fact that the Indian of North America possessed a distinctive art which promises to be of great value in a country which heretofore has been obliged to draw its models from the countries of the eastern hemisphere.

(De Cora Dietz A., 1912 : 86)

Pour Angel de Cora, cependant, qui parle d'indigénéité de l'art dans la citation suivante, les arts amérindiens n'émanent guère tant de marges créatrices, mais bien plutôt d'un centre, la terre américaine, sur lequel les colons, venant de marges européennes, tentent de se recentrer, mais qui est irrigué de racines indigènes qui donnent naissance à des productions artistiques en phase avec l'environnement dans lequel elles émergent :

As all peoples have treasured the history of their wanderings in some form, so has the American Indian had his pictograph and symbolic records, and with the progress of time he has evolved it into a system of designing, drawing his inspiration from the whole breadth of his native land. His art like himself is indigenous to the soil of his country, where, with the survival of his latent abilities, he bravely offers the best productions of his mind and hand which shall be a permanent record of the race.

(De Cora Dietz A., 1912 : 87)

Ce renversement de perspective, qui induit une inversion du centre et des marges - les Amérindiens se retrouvant au centre et les colons venant des marges - est un motif que l'on retrouve chez d'autres auteurs contemporains de De Cora, qui en décrivent les conséquences sur la beauté des créations des êtres, d'une part, et sur leur psychologie et les relations qu'ils instaurent avec autrui d'autre part. Dans Sundown, l'auteur osage John Joseph Mathews écrit de son personnage autobiographique, qui contemple les paysages urbains qui défilent devant la fenêtre du train qui le ramène à l'université :

Chal did not know the reason for this ugliness; this ugliness which white men seemed to produce. He did not know that these buildings were expressions of a race still influenced by an environment thousands of miles across the ocean, and that these foreign expressions were due to the fact that the race was not yet in adjustment with the new environment. He felt simply that these things were not beautiful.

(Mathews J. J., 1934 : 90)

Comme Angel de Cora et Mathews, Luther Standing Bear (lakota) évoque l'indigénéité des Amérindiens - « The American Indian is of the soil » (Standing Bear L., 1933 : 247) et le déracinement des Européens - "The white man does not understand the Indian for the reason that he does not understand America. He is too far removed from its formative processes. The roots of the tree of his life have not yet grasped the rock and soil » (Standing Bear L., 1933 : 248) - pour expliquer que le fameux " problème indien » est en fait un terme inapproprié, puisque le véritable problème provient du décentrement des colons :

There is, I insist, no Indian problem as created by the Indian himself. Every problem that exists today in regard to the native population is due to the white man's cast of mind, which is unable, at least reluctant, to seek understanding and achieve adjustment in a new and a significant environment into which it has so recently come.

(Standing Bear L., 1933 : 248-249) 
amérindien, comme toute production amérindienne, est donc l'expression créatrice d'un continent, enracinée tellement profondément, dans les êtres comme dans la terre sur laquelle ils évoluent, qu'elle ne peut disparaître complètement : "The Indian in his native dress is a thing of the past, but his art that is inborn shall endure. He may shed his outer skin, but his markings lie below that and should show up only the brighter » (De Cora Dietz A., 1912 : 87).

\section{Conclusion}

41 S'exprimant depuis des marges qu'ils cherchaient à rendre visibles, jusqu'à parfois suggérer un renversement des marges et du centre, les intellectuels et militants amérindiens du début du $\mathrm{xx}^{\mathrm{e}}$ siècle, organisés ou non au sein de la SAI, ne proposaient pas une assimilation qui aboutirait à la disparition des Amérindiens dans le tissu social états-unien. Ils prônaient une intégration des Amérindiens à la société états-unienne en tant que « peuple américain » parmi d'autres :

The thinking Indian of today, viewing events and conditions in their true perspective, asks, therefore, that the entire race may be given the freedom which will enable it to develop normally as an American people in America.

(SAI, 1912:5)

L'intervention de l'artiste Angel de Cora nous fournit, avec l'art amérindien, une métaphore pour illustrer les enjeux de la puissance créatrice des marges : les capacités des Amérindiens à s'ajuster à des conditions modernes et à contribuer au développement $\mathrm{du}$ pays avec leurs particularismes culturels. Il s'agissait, pour s'intégrer sans disparaître, de participer au tissage du tissu social états-unien en y insérant leurs propres motifs, issus de leurs traditions culturelles et artistiques, ainsi que leurs compétences. Ainsi, les cultures amérindiennes, manifestées dans l'art ou ailleurs, peuvent fournir à la culture états-unienne une identité vraiment américaine, distincte des cultures laissées dans le Vieux Monde. C'est ce genre de contribution, qui est aussi un procédé de survivance, qu'appellent de leurs vœux les intellectuels amérindiens de l'ère progressiste.

Ce que disait Angel de Cora au sujet de l'art, Oskison en parlait en termes génériques, et il se voulait optimiste quant à l'acceptation de valeurs et qualités amérindiennes par l'ensemble de la société états-unienne :

We must not run away from here with the idea that we alone appreciate Indian civilization. Some white people with whom I have talked are anxious to [...] help to perpetuate all ideas and organizations that are distinctly Indian, and which are worth preserving [...] Encourage in some way the perpetuation of the Indian industries [...] The one idea being to keep for the study of Americans in general those things which are distinctive and which represent an element in human progress.

(SAI, $1912: 79)$

Enfin, lorsqu'on ajoute à toutes ces considérations l'idée développée notamment par De Cora, Standing Bear et Mathews de la beauté intrinsèque de toute création indigène du fait même de cette indigénéité, il se dégage ce que l'on peut maladroitement appeler, en traduisant une expression utilisée dans les documents fondateurs de la SAI, une « conscience de race »: " The time has come when the Indian should be encouraged to develop self-help. This can be achieved only with the attainment of a race consciousness and a race leadership » (SAI, 1912 : 9). L'un des objectifs de la SAI était 
notamment de «s'opposer à tout mouvement qui pourrait être au détriment de la race» ("to oppose any movement which appears detrimental to the race», 7) et de promouvoir « le bien de la race» («the welfare of the race», 7), jamais au détriment, cependant, de la nation états-unienne : «the honor of the race and the good of the country will always be paramount " (7), mais toujours pour le bien de chaque individu amérindien : « the highest interests of the Indian as a race and as an individual » (14).

Cette dimension du discours intellectuel amérindien du début $\mathrm{du} \mathrm{xx}^{\mathrm{e}}$ siècle est à resituer dans une histoire intellectuelle amérindienne qui verra dans la seconde moitié du siècle ce que d'aucuns appellent " conscience ethnique » ou " fierté ethnique »:

Changes in American politics of the civil rights movement created an atmosphere that increased ethnic consciousness, ethnic pride, and ethnic mobilization among all ethnic groups, including American Indians. The resulting "Red Power" Indian political activist movement of the 1960s and 1970s started a tidal wave of ethnic renewal that surged across reservation and urban Indian communities, instilling ethnic pride and encouraging individuals to claim and assert their "Indianness." (Nagel J., 1995 : 948)

Il est d'autant plus important de comprendre que c'est bien de cela qu'il s'agissait déjà au début du $\mathrm{xx}^{\mathrm{e}}$ siècle que l'on a eu tendance à considérer que ce qui se passait dans les années 1960 et 1970 était nouveau :

For America's ethnic minorities it was a time to cast off negative stereotypes, to reinvent ethnic and racial social meanings and self-definitions, and to embrace ethnic pride. For American Indians it marked the emergence of supratribal identification, the rise of Indian activism, and a period of increased Indian ethnic pride.

(Nagel J., 1995 : 955)

C'est ce qu'écrit Joane Nagel au sujet des années 1960 et 1970. Or, comme j'ai tenté de le démontrer dans cet article, le « rejet des stéréotypes négatifs », la "réinvention des définitions de soi », "l'identification supratribale», "l'émergence de l'activisme indien », et "l'augmentation de la fierté ethnique amérindienne » étaient déjà des symptômes de l'ère progressiste.

\section{BIBLIOGRAPHIE}

Allen, Chadwick, « Introduction: Locating the Society of American Indians », American Indian Quarterly 37.3, The Society of American Indians and its Legacies: A Special Combined Issue of SAIL and AIQ (Summer 2013), p. 3-22

Bluesky, Bertram, « Higher Education in Public Schools and Colleges for the Indian », Quarterly Journal of the Society of American Indians, January-March 1914, p. 75-76

Brown, Kirby, « Citizenship, Land, and Law: Constitutional Criticism and John Milton Oskison's Black Jack Davy ", Studies in American Indian Literatures 23.4 (Winter 2011), p. 77-115

Conley, Robert J., The Cherokee Nation, A History. Albuquerque, University of New Mexico Press, 2005 
De Cora Dietz, Angel, « Native Indian Art », SAI, Report of the Executive Council on the Proceedings of the First Annual Conference of the Society of American Indians, Washington, D.C., 1912, p. 82-87

DeForest Davis, Oscar, "The Indians in the Professions ", SAI, Report of the Executive Council on the Proceedings of the First Annual Conference of the Society of American Indians, Washington, D.C., 1912, p. 98-100

Knocksofttwo, Henry, « Educated Indians are Successful », Quarterly Journal of the Society of American Indians, January-March 1914, p. 77-78

Lake Mohonk Conference, Proceedings of the Third Annual Meeting of the Lake Mohonk Conference of Friends of the Indian, Held October 7 to 9, 1885, Philadelphia, 1886

Larré, Lionel, « John Milton Oskison and Assimilation », American Indian Quarterly 31.1-2, Winter / Spring 2013, p. 3-33

Littlefield, Jr., Daniel F. \& James W. Parins, « Short fiction writers of the Indian Territory », American Studies, Lawrence, KS, 23.1 (1982), p. 23-38

Maddox, Lucy, Citizen Indians: Native American Intellectuals, Race, and Reform, Ithaca, Cornell University Press, 2005

Mathews, John Joseph, Sundown, 1934, Norman, University of Oklahoma Press, 1988

Montezuma, Carlos, «The Reservation is Fatal to the Development of Good Citizenship », Quarterly Journal of the Society of American Indians, January-March 1914, p. 69-74

Montezuma, Carlos, « Let My People Go », American Indian Magazine, January-March 1916, p. 32-33

Nagel, Joane, « American Indian Ethnic Renewal: Politics and the Resurgence of Identity ", American Sociological Review, 60.6, December 1995, p. 947-965

Oskison, John Milton, « The Indian in the Professions » in Larré, Lionel, ed. Tales of the Old Indian Territory and Essays on the Indian Condition, Lincoln, University of Nebraska Press, 2012, p. 399-403. First published in SAI, Report of the Executive Council on the Proceedings of the First Annual Conference of the Society of American Indians, Washington, D.C., 1912, p. 94-98

Oskison, John Milton, « Making an Individual of the Indian » in Larré, Lionel, ed. Tales of the Old Indian Territory and Essays on the Indian Condition, Lincoln, University of Nebraska Press, 2012, p. 380-390. First published in Everybody's Magazine 16.6, June 1907, p. 723-33

Sloan, Thomas L., "Address of Thomas L. Sloan on "Reservation System-Administration" ", SAI. Report of the Executive Council on the Proceedings of the First Annual Conference of the Society of American Indians, Washington, D.C., 1912, p. 112-121

Society of American Indians, Report of the Executive Council on the Proceedings of the First Annual Conference of the Society of American Indians, Washington, D.C., 1912

Standing Bear, Luther, Land of the Spotted Eagle, 1933, Lincoln, University of Nebraska Press, 1978

Warrior, Robert, "The SAI and the End(s) of Intellectual History », American Indian Quarterly 37.3, The Society of American Indians and its Legacies: A Special Combined Issue of SAIL and AIQ, Summer 2013, p. 221-235 


\section{NOTES}

1. Pour une liste exhaustive des critiques adressées à Oskison, et leur déconstruction, voir Lionel Larré, «John Milton Oskison and Assimilation », American Indian Quarterly 31.1-2 (Winter/Spring 2013), 3-33.

\section{RÉSUMÉS}

Au début du $\mathrm{xx}^{\mathrm{e}}$ siècle, des Amérindiens d'horizons différents et de cultures diverses s'organisent pour faire entendre leur voix dans un contexte de politique fédérale assimilationniste à leur égard. Ils produisent alors un discours riche et complexe sur une variété de sujets auxquels ils étaient confrontés. Ce faisant, ils initiaient une reconquête de leur souveraineté intellectuelle, exprimant des positions nuancées et constructives par rapport aux politiques fédérales de l'époque. Ainsi, dans cette marge de la société états-unienne, ces intellectuels amérindiens libéraient une puissance créatrice à même de recentrer les Amérindiens au sein de la culture et de la société dominantes.

At the beginning of the $20^{\text {th }}$ century, Native Americans from various tribes and walks of life organized and expressed themselves in the context of assimilationist federal policies. They produced a rich and complex discourse about diverse problems that Native Americans were confronted to at the time. Doing so, they initiated a conquest of their intellectual sovereignty, expressing nuanced and constructive positions regarding federal policies that targeted them. Thus, in the margins of US society, these Native American intellectuals exerted a powerful creative force likely to integrate Native Americans within US culture and society.

A principios del sigloxx

, los indígenas de horizontes diferentes y culturas diversas se organizan en los Estados Unidos para hacer oír sus voces en un contexto de política federal asimilista. Elaboran entonces un discurso abundante y complejo sobre una variedad de temas a los que se enfrentaban y emprenden así una reconquista de su soberanía intelectual, expresando posiciones complejas, matizadas y constructivas sobre las políticas federales de la época. De este modo, en el margen de

la sociedad estadounidense, los intelectuales indígenas liberan una potencia creadora capaz de volver a incluir a sus semejantes en el seno de la cultura y de la sociedad dominantes.

\section{INDEX}

Keywords : Native Americans, Indigenous studies, Society of American Indians (SAI), intellectual sovereignty, Progressive Era, United States, assimilationism

Mots-clés : Amérindiens, études amérindiennes, SAI (Society of American Indians), souveraineté intellectuelle, ère progressiste, États-Unis, assimilationnisme

Palabras claves : Pueblos indígenas, estudios amerindios, Society of American Indians (SAI), soberanía intelectual, era progresista, Estados Unidos, asimilismo 


\section{AUTEUR}

\section{LIONEL LARRÉ}

Lionel Larré est membre de l'EA 4196 CLIMAS professeur de civilisation américaine à l'Université Bordeaux Montaigne, où il enseigne surtout l'histoire des Amérindiens. Il est l'auteur de nombreux articles sur l'histoire et les représentations des Amérindiens, de Autobiographie amérindienne. Pouvoirs et résistance de l'écriture de soi (Presses universitaires de Bordeaux, 2009), et de Histoire de la nation cherokee (Presses universitaires de Bordeaux, 2014). Il a également dirigé la publication d'un volume des écrits de John Milton Oskison, un auteur cherokee de la première moitie du $\mathrm{xx}^{\mathrm{e}}$ siècle : Tales of the Old Indian Territory and Essays on the Indian Condition (University of Nebraska Press, 2012). Il est enfin co-créateur de la revue Elohi, Peuples indigènes et environnement (https://journals.openedition.org/elohi/). Il est actuellement le directeur de l'UFR Langues et Civilisations de l'Université Bordeaux Montaigne. 